\title{
Isolation and Optimization of Phytase from Pseudomonas aeruginosa and Aspergillus niger Isolated from Poultry Faeces
}

\author{
Faith O. Ogbonna ${ }^{1}$, Mohammed A. Milala ${ }^{2}$, Mohammad Abubakar ${ }^{2}$ and Bulama Burah ${ }^{2 *}$ \\ ${ }^{1}$ Department of Biochemistry, Faculty of Science, Gombe State University, Gombe, Nigeria \\ ${ }^{2}$ Department of Biochemistry, Faculty of Science, University of Maiduguri, Maiduguri, Nigeria \\ *Corresponding author
}

\section{A B S T R A C T}

Phytases are enzymes that can hydrolyze phytic acid to less phosphorylated myo-inositol derivatives, releasing inorganic phosphate. In this study, phytase producing bacterium

Keywords

Phytase, Phytic acid,

Pseudomonas

aeruginosa,

Aspergillus niger and

Poultry faeces.

Article Info

Accepted:

26 September 2017

Available Online:

10 November 2017
Pseudomonas aeruginosa and fungus Aspergillus niger isolated from poultry faeces were investigated and the production of phytase was optimized. Standard method was used to assay for Phytase activity. The time course production of phytase by $P$. aeruginosa showed that optimum phytase production was at 24 hours of incubation while that of $A$. niger was at 48 hours of incubation. Effects of agricultural substrates on phytase production by $P$. aeruginosa revealed the maximum activity $(0.604 \mu \mathrm{mol} / \mathrm{min})$ of phytase with sorghum grain as agricultural substrate while maximum phytase activity $(1.2 \mu \mathrm{mol} / \mathrm{min})$ by $A$. niger was obtained when millet grain was used. Effects of $\mathrm{pH}$ and temperature showed that optimum phytase activity from $P$. aeruginosa and A. niger was at $\mathrm{pH} 6$ and 7 respectively while both preferred temperature of $37^{\circ} \mathrm{C}$. Lactose was the best source of carbon for both. Yeast extract was observed as the best nitrogen for A. niger while urea for P. aeruginosa. In conclusion, The enzyme (phytase) was both thermostable and acid stable, can find applications in animal feed industry for improving nutritional status of the feed and combating environmental phosphorus pollution.

\section{Introduction}

Phytic acid also known as inositol hexaphosphate (IP6) or phytate is the storage form of Phosphorous in all grains and oil seeds, (Jacela et al., 2010). Phytic acid occurs primarily as salts of mono- and divalent cations (e.g. potassium-magnesium salt in rice and calcium-magnesium-potassium salt in soybeans) in discrete regions of cereal grains and legumes. It accumulates in seeds and grains during ripening, accompanied by other storage substances such as starch and lipids (Reddy et al., 1989). Phytic acid has been shown to have a strong anti-nutritive effect
(Pallauf and Rimbach, 1996). This effect is based on the unusual molecular structure of phytic acid. Phytic acid effectively binds different mono-, di-, and trivalent cations and their mixtures, forming insoluble complexes (Reddy et al., 1989). The formation of insoluble phytate mineral complexes in the intestinal tract prevents mineral absorption. This reduces the bioavailability of essential minerals (Davies, 2002). Phytase is an enzyme that catalyzes the hydrolysis of phytic acid - an indigestible, organic form of phosphorus that is found in grains and oil 
seeds and releases a usable form of inorganic phosphorus. While phytases have been found to occur in animals, plants, fungi and bacteria, phytases have been most commonly detected and characterized from fungi (Mullaney and Ullah 2003). The enzyme is used as an animal feed supplement, often in poultry and swine to enhance the nutritive value of plant material by liberation of inorganic phosphate from phytic acid (Golovan et al., 2001). The anti-nutritive effect of phytate could be solved by hydrolysis of phytate using supplemental phytase (Simell et al., 1989). Phytases also enhance phosphorus utilization from phytate (Selvamohan et al., 2012). Therefore, phytase has become an important industrial enzyme and an object of extensive research.

Phytases can be found in plants, certain animal tissues and microorganisms like fungi, bacteria and yeast (Nagai and Funahashi, 1962). Research has indicated that several strains of bacteria, yeast and fungi can produce high yields of phytase with application at the industrial scale (Chunshan et al., 2001). Phytases have been detected in several types of bacteria, such as bacilli, enterobacteria, anaerobic ruminal bacteria and pseudomonas sp. Cosgrove (1969) reported the dephosphorylation of the hexaphosphates of myo-inositol by Pseudomonas sp. phytase. Ruminants digest phytate through the action of phytases produced by microbial flora in the rumen. The anaerobic gut fungi and bacteria present in the microflora of ruminants are responsible for the primary colonization of plant material within the rumen. The inorganic phosphate hydrolyzed from phytate by phytases is utilized by both the microflora and the ruminant host (Yanke et al., 1998). The situation is different with monogastric animals. Monogastrics, such as pig, poultry and fish are unable to metabolize phytic acid, since they lack gastrointestinal phytase. Therefore, inorganic phosphate is added to their feed to meet the phosphate requirement.
This increases costs and contributes to phosphate pollution problems. The supplementation of animal feed with phytase enables the assimilation of phosphate in the feed ingredients and diminishes the amount of phosphate in the manure and subsequently reaching the environment (Nasi, 1990). It is against this background that this study is designed to isolate phytase producing bacterium and fungus from poultry faeces and optimize the condition controlling the phytase production.

\section{Materials and Methods}

\section{Isolation and identification of Pseudomonas aeruginosa and Aspergillus niger}

Isolation of the phytase-producing bacterium $P$. aeruginosa was carried out by sampling poultry faeces collected from a poultry farm at Gombe State University Zoo, Nigeria, while A. niger was isolated from poultry faeces collected from a poultry farm in Maiduguri, Borno State, Nigeria. One (1) g of poultry faeces was serially diluted with distilled water and appropriate dilutions were poured unto the solidified culture media.

The culture media were incubated at $37^{\circ} \mathrm{C}$ for 24 hours in an incubator. After incubation, bacterial and fungal colonies were observed and sub-cultured on appropriate culture media to obtain pure cultures. Bacterial and fungal strains were subjected to a series of tests such as gram staining, motility test and biochemical tests for identification as described by Samson, (2001). P. aeruginosa and $A$. niger isolates were identified by their morphological appearance and biochemical characteristics.

\section{Assay for phytase production}

Phytase production was analyzed using the method described by Singh and 
Satyanarayana, (2008). The phytase activity was determined by calculating the amount of liberated inorganic phosphate. The enzyme activity was assayed as follows; a drop of the isolate was transferred to peptone water containing $1 \%$ sodium chloride, $0.1 \%$ dipotassium hydrogen phosphate and $0.01 \%$ magnesium sulphate which aid in production of extracellular phytase.

The reaction mixture consist of $2.4 \mathrm{ml}$ phytic solution $(0.32 \mathrm{~g}$ sodium phytate, dissolved in $50 \mathrm{ml}$ of $0.2 \mathrm{M}$ sodium acetate acid buffer with $\mathrm{pH} 5.5), 1 \mathrm{ml}$ of $0.1 \mathrm{M}$ magnesium sulphate, $0.2 \mathrm{ml}$ of the crude enzyme and 0.4 $\mathrm{ml}$ distilled water. It was incubated at room temperature for 15 minutes followed by stopping the reaction by adding $0.5 \mathrm{ml}$ of $10 \%$ Trichloroacetic acid. Then $1 \mathrm{ml}$ distilled water and $2.5 \mathrm{ml}$ of Taussky Schoor reagent solution (freshly prepared) were added to the mixture, the absorbance was measured at 660 $\mathrm{nm}$ using the spectrophotometer. Phytase activity was calculated using phosphorus standard. One unit of phytase activity is equivalent to $1 \mu \mathrm{g}$ of phosphorus released under the different assay conditions.

\section{Parameters affecting phytase production}

\section{Effect of incubation time on phytase production}

The time course production of phytase by $P$. aeruginosa and $A$. niger was carried out at different incubation time (24, 48, 72 and 96 hours) after inoculation.

\section{Effect of different agricultural substrates on phytase production}

Phytase production with agricultural substrate was studied by using different substrates such as sorghum and millet grains at $1 \%(\mathrm{w} / \mathrm{v})$ level. This was studied with different time intervals of 24, 48, 72 and 96 hours.
Effect of different carbon sources on phytase production

Suitability of different carbon sources such as lactose and fructose were studied at $0.5 \%$ level. The effects of carbon sources on phytase production were noticed at different time intervals (24, 48, 72 and 96 hours).

\section{Effect of pH on phytase production}

The effect of incubation $\mathrm{pH}$ on phytase production was determined by varying the $\mathrm{pH}$ values 5, 6, 7 and 8 . Their influence on phytase production was determined at different time intervals $(24,48,72$ and 96 hours).

\section{Effect of different incubation temperature on phytase production}

The organisms inoculated in the production media were incubated at different temperatures of $30^{\circ} \mathrm{C}, 37^{\circ} \mathrm{C}, 40^{\circ} \mathrm{C}$, and $45^{\circ} \mathrm{C}$ and their influence was noticed at different time intervals (24, 48, 72 and 96 hours).

\section{Effect of different nitrogen sources on phytase production}

The effect of nitrogen sources on phytase production was determined using urea and yeast extract at $0.5 \%(\mathrm{w} / \mathrm{v})$ level as nitrogen sources and their influence was observed at different time intervals $(24,48,72$ and 96 hours).

\section{Results and Discussion}

Figure 1, effect of incubation time on phytase production, the maximum production of phytase by $P$. aeruginosa was observed at 24 hours while the maximum phytase production by $A$. niger was observed at 48 hours of incubation. The activity of the enzyme gradually decreased as incubation time 
increased. While the effect of different agricultural substrates on phytase activity showed maximum enzyme activity $(0.6 \mu \mathrm{mol} / \mathrm{min})$ by $P$. aeruginosa after 72 hours of incubation with sorghum grain as the substrate while maximum phytase activity $(1.2 \mu \mathrm{mol} / \mathrm{min})$ by $A$. niger was obtained when millet grain was used as shown in figure 2 .

The effect of different carbon sources on phytase activity revealed that both $P$. aeruginosa and $A$. niger preferred lactose as the best source of carbon than fructose as shown in figure 3 .

Figure 4 shows the effect of $\mathrm{pH}$ on phytase activity. The maximum phytase enzyme activity by $P$. aeruginosa was observed at $\mathrm{pH}$ 6 after 72 hours of incubation, while phytase activity by $A$. niger was optimum at $\mathrm{pH} 7$ after 72 hours of incubation.

Figure 5 is the effect of different incubation temperature on phytase activity. The optimum phytase activity by both $P$. aeruginosa and $A$. niger was observed at $37^{\circ} \mathrm{C}$ after 72 hours incubation. The phytase activity gradually decreased with increase in temperature.
Figure 6 presents the effects of different nitrogen sources on phytase activity. The maximum phytase activity by $P$. aeruginosa $(0.93 \mu \mathrm{mol} / \mathrm{min})$ was observed at 24 hours when urea was used as source of nitrogen while A. niger preferred yeast extract as the best source of nitrogen.

It is well known that optimization of process parameters plays an important role in improving enzyme yield, making enzyme production cost effective and economically feasible (Sasirekha et al., 2012).

Shorter incubation periods translate into shorter opportunity for spoilage. From the result obtained, the maximum phytase activity was observed at 24 hours and 48 hours of incubation by $P$. aeruginosa and $A$. niger respectively. The enzyme activity gradually decreased as incubation time increases. After 72 hours, the production level of the enzyme has reduced significantly; when the enzyme production and growth of the microorganism decreased, it can be attributed to the reduced availability of nutrients and accumulation of waste products that have gross effects on enzyme activity (Romero et al., 1998).

Fig.1 Time course production of phytase by Pseudomonas aeruginosa and Aspergillus niger using phytic acid as substrate

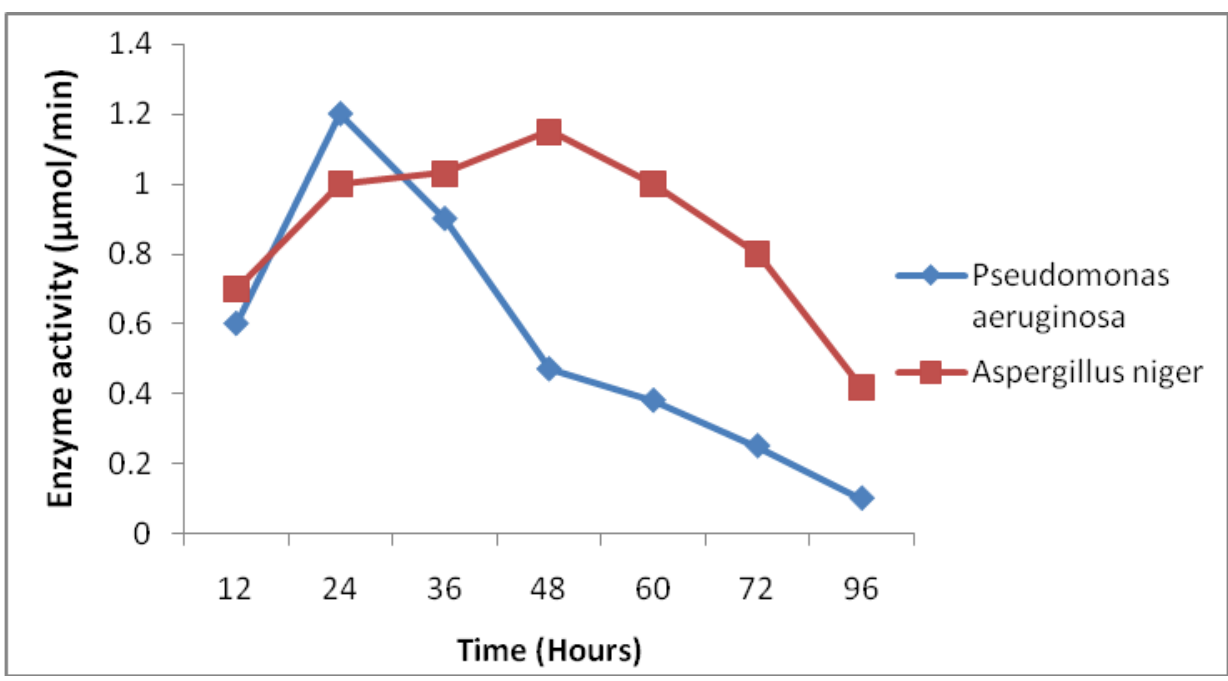


Fig.2 Effect of agricultural substrates (sorghum and millet grains) on phytase activity by Pseudomonas aeruginosa and Aspergillus niger

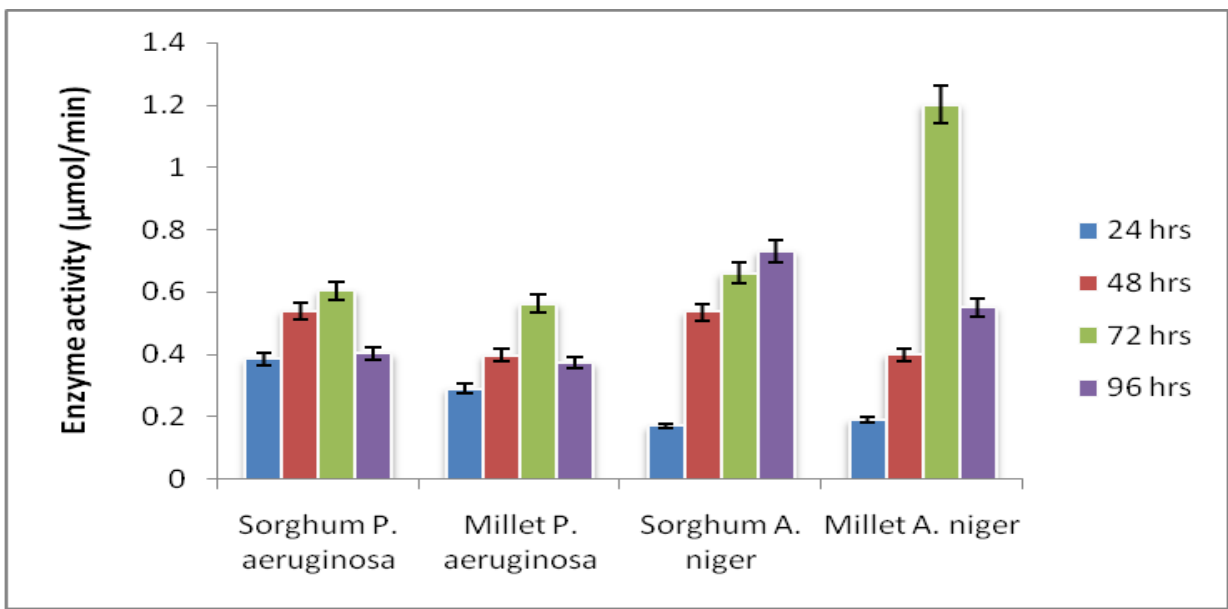

Fig.3 Effect of different carbon sources (fructose and lactose) on phytase activity by Pseudomonas aeruginosa and Aspergillus niger

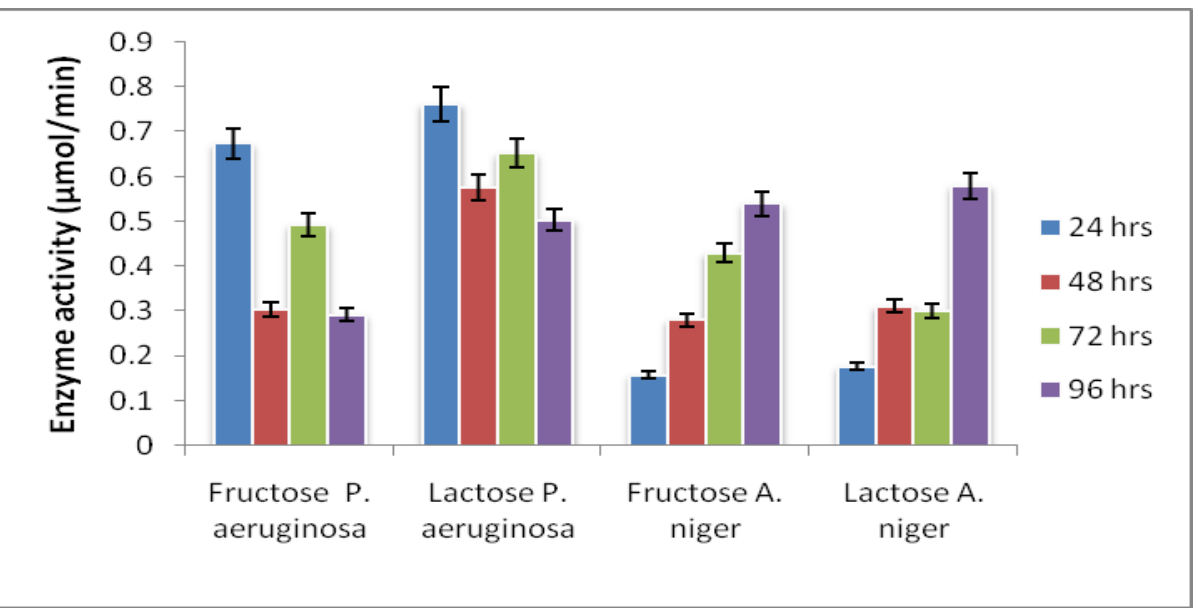

Fig.4 Effect of $\mathrm{pH}$ on phytase activity by Pseudomonas aeruginosa and Aspergillus niger

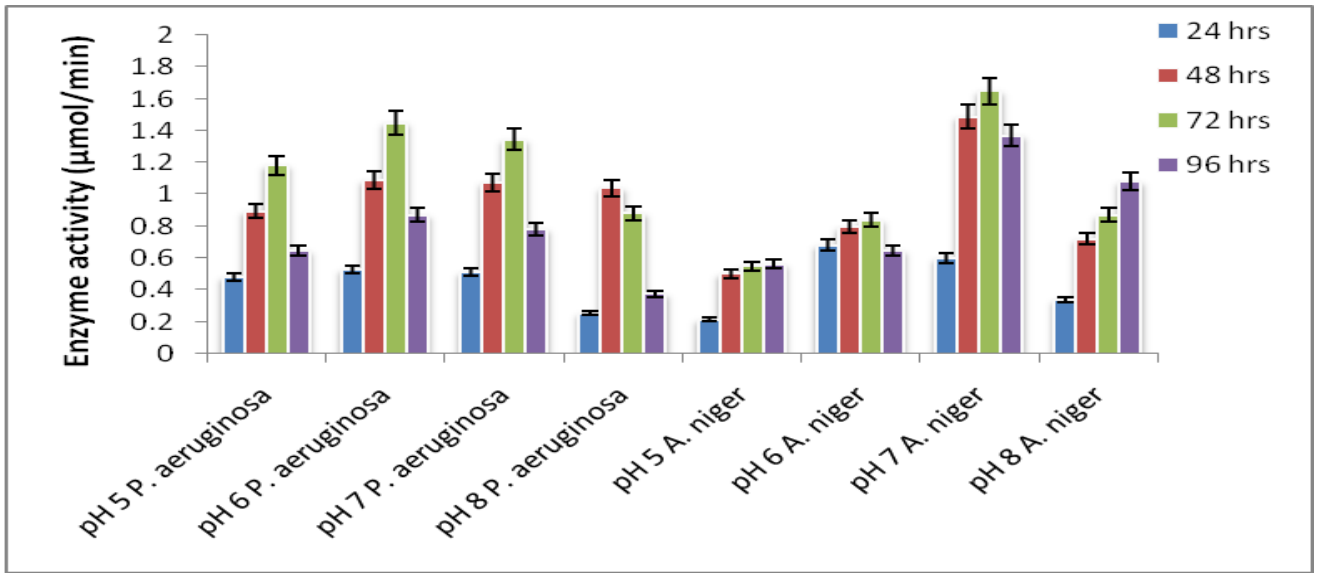


Fig.5 Effect of different temperature $\left(30,37,40\right.$ and $\left.45^{\circ} \mathrm{C}\right)$ on phytase activity by Pseudomonas aeruginosa and Aspergillus niger

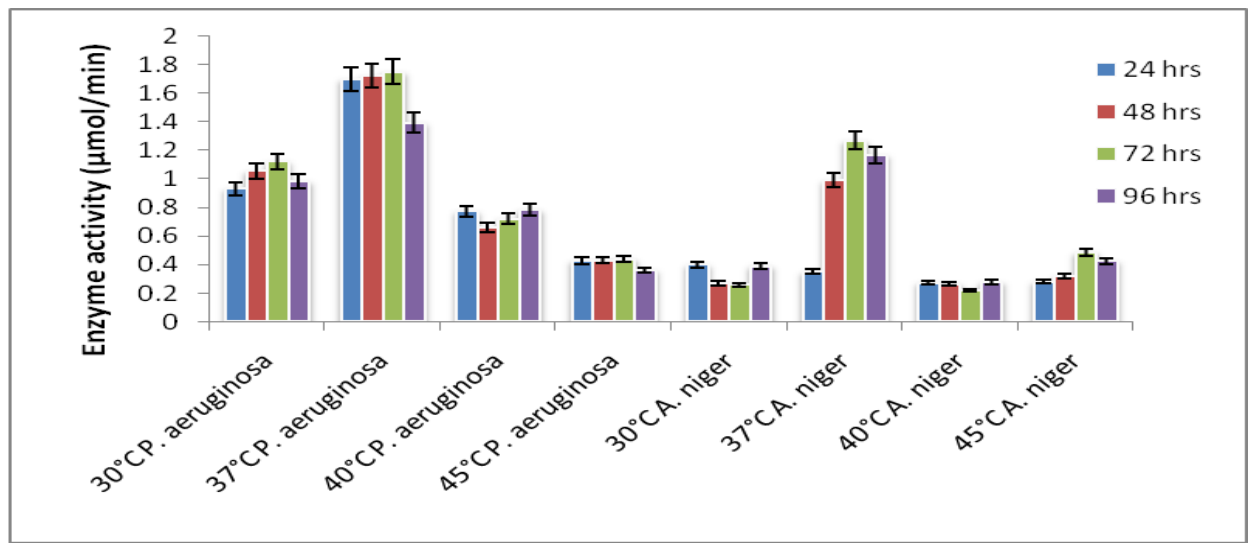

Fig.6 Effect of different nitrogen sources (urea and yeast extract) on phytase activity by Pseudomonas aeruginosa and Aspergillus niger

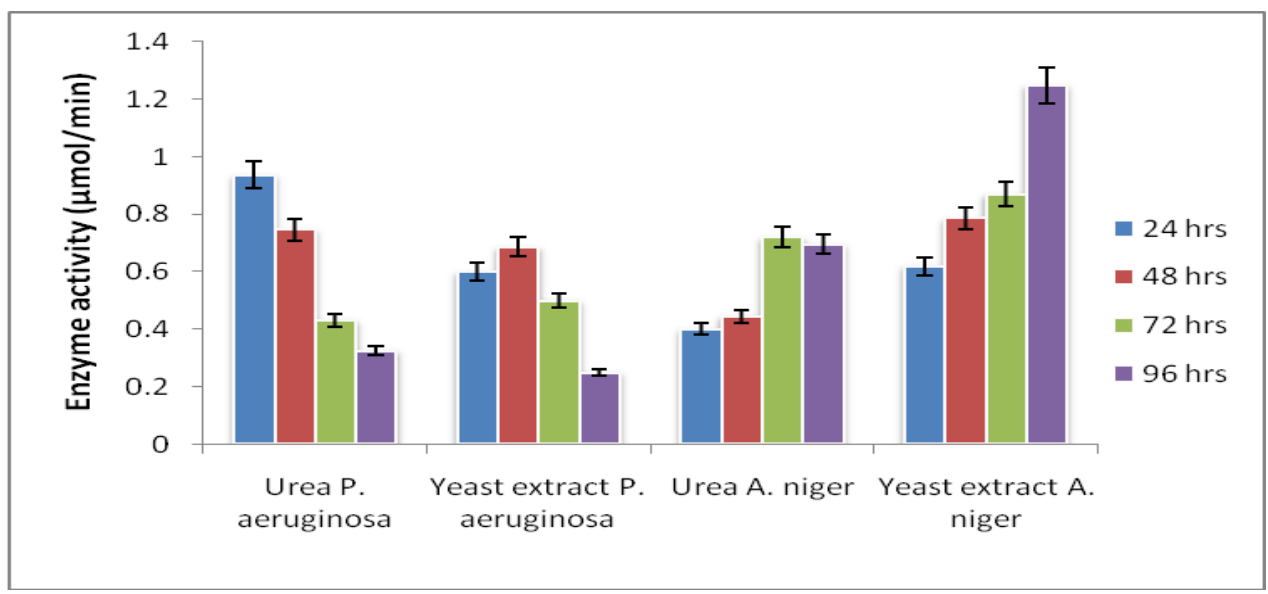

Among the different agricultural substrates studied, maximum enzyme activity $(0.6 \mu \mathrm{mol} / \mathrm{min})$ by $P$. aeruginosa was obtained after 72 hours of incubation when sorghum grain was used while maximum phytase activity by $A$. niger was observed when millet grain was used as agricultural substrate. Using sorghum as agricultural substrate provides many advantages especially to reduce the production cost of phytase and this agrees with the findings of Sasirekha et al., (2012).

Loewus (2002) also reported that millet contains more phytic acid $(0.48 \mathrm{~g} / 100 \mathrm{~g})$, this may be the reason why millet is a better substrate.
Result obtained from the study also showed that maximum phytase activity from both $P$. aeruginosa and $A$. niger was observed when lactose was used as source of carbon as compared to fructose. Carbohydrates are essence energy sources for most of heterotrophic organisms. Singh and Satyanarayana (2011) also studied the effect of different carbon sources. Among various carbon sources tested, glucose supported highest phytase production from Sporotrichum thermophile as compared to other carbon sources. Aspergillus niger produced high phytase titres, when grown in a medium containing corn starch along with glucose (Volfova et al., 1994). 
$\mathrm{pH}$ is another important parameter which determine the growth and production of phytase by $P$. aeruginosa and $A$. niger. From the result, maximum phytase activity $(1.45 \mu \mathrm{mol} / \mathrm{min})$ from $P$. aeruginosa was obtained at $\mathrm{pH} 6$ and at least $80 \%$ of the maximal activity was observed at $\mathrm{pH}$ values between 4.0 and 7.0. Meanwhile $A$. niger preferred $\mathrm{pH} 7$ for optimum phytase production. As the $\mathrm{pH}$ increase, decrease in enzyme activity was observed. Increase in $\mathrm{pH}$ affects the charges on the amino acids within the active site such that the enzyme is not able to form enzyme-substrate complex. Thus, there is decrease in enzyme activity (Bhavsar et al., 2010).

Temperature is one of the most critical parameters to be controlled in any bioprocess. The temperature requirement of the organism is based on the nature of the environment where they grow. The effect of temperature on phytase production revealed that maximum yield from both $P$. aeruginosa and $A$. niger was obtained at $37^{\circ} \mathrm{C}$. Optimum temperature for the production of phytase for most of the microorganisms lies in the range of $25^{\circ} \mathrm{C}$ to $37^{\circ} \mathrm{C}$ (Vohra and Satyanarayana, 2003). A decrease in enzyme yield was observed with further increase in temperature; hence, production of phytase by the microorganisms was determined to be growth-related, which is a common phenomenon in many fermentation processes.

Result obtained from the work showed that the inorganic nitrogen source urea was found to be a better nitrogen source for the isolated bacterial culture $(P$. aeruginosa) $(0.93 \mu \mathrm{mol} / \mathrm{min})$ after incubation at 24 hours whereas the fungal isolates (A. niger) prefer ammonium sulphate as a better nitrogen source. The nitrogen sources are secondary energy sources for the organisms which play an important role in the growth of the organisms and the production of the enzyme. On the contrary, Vohra and Satyanarayana, (2003) reported that $\left(\mathrm{NH}_{4}\right)_{2} \mathrm{HPO}_{4}$ was the most favourable nitrogen source for Mycelophoythora thermophila phytase production.
From the study, Pseudomonas aeruginosa and Aspergillus niger isolated from poultry faeces are capable of producing phytase enzyme in culture media. The enzyme was able to tolerate broad temperature and $\mathrm{pH}$ range of $37^{\circ} \mathrm{C}$ to $50^{\circ} \mathrm{C} ; 4$ to 8 . Phytase production was enhanced due to optimization. The enzyme being thermostable and acid stable, can find application in animal feed industry for improving nutritional status of the feed and combating environmental phosphorus pollution.

\section{References}

Bhavsar, K., Shah, P., Soni, S. K., and Khire, J. M. (2010). Influence of Pretreatment of Agriculture Residues on Phytase Production by Aspergillus niger NCIM 563 under Submerged Fermentation Conditions. African Journal of Biotechnology 7, 1101-1106.

Chunshan, Q, Linghua Z, Yunji W and Yoshiyuki O, (2001). Production of phytase in slow phosphate medium by a novel yeast Candida krusei. Journal of Bioscience and Bioengineering, 92:154160.

Cosgrove, C. W. (1969). Study of Phytase and Fluoride Effects in Germinating Corn Seeds. Cereal Chemistry, 44:2--142.

Davies, N. T. (2002). Effects of phytic acid on Mineral Availability. In Dietary Fiber in Health and Disease. Vahoung, G. V. and Kritchevsky, D., Eds., Plenum Press, New York.

Golovan, S. P., Meidinger, R. G., Ajakaiye, A., Cottrill, M., Wiederkehr, M. Z., Barney, D. J., and Forsberg, C. W. (2001). Pigs Expressing Salivary Phytase Produce Low-phosphorus Manure. Nature biotechnology, 19(8), 741-745.

Jacela, J.Y., J.M. DeRouchey, M.D. Tokach, R.D. Goodband, J.L. Nelssen, D.G. Renter and S.S. Dritz, 2010. Feed Additives for Swine: Fact Sheets Prebiotics and Probiotics and Phytogenics. Journal of Swine Health Production, 18: 87-91. 
Loewus, F.A., (2002). Biosynthesis of Phytate in Food Grains and Seeds. In: Food Phytate, Reddy, N.R. and Sather, S.K. (Eds). CRC Press, Boca Raton, Florida, pp: 53-61.

Mullaney EJ. and Ullah AH. (2003). The Term Phytase Comprises Several Different Classes of Enzymes. Biochemstry Biophysics Research Community. 312 (1): 179-184.

Nagai, C.H. and Funahash, Y. (1962). The Colorimetric Determination of Phosphorus. Journal of Biological Chemistry 66:376-400.

Nasi, M. (1990). Microbial Phytase Supplementation for Improving Availability of Plants Phosphorus in the Diets of Growing Pigs. Agricultural Science, 62: 435-442.

Pallauf, J. and Rimbach, G. (1996). Nutritional Significance of Phytic acid and Phytase. Archives of Animal Nutrition. 50, 301319.

Reddy, N. R., Pierson, M. D., Sathe, S. K. and Salunkhe, D. K. (1989). Phytates in Cereals and Legumes. CRC Press, Inc., Boca Raton, Florida. Pp. 39-56

Romero, F., García, L., and Díaz, M. (1998). Protease Production from Whey at High Concentrations by Serratia marcescens. Resource and Environmental Biotechnology, 2: 93-115.

Samson R.A, (2001). Introduction to Food Borne Microorganisms, American Society of Microbiology, America, pp 196-197.

Sasirekha, B., Bedashree, T. and Champa, K. (2012). Optimization and Partial Purification of Extracellular Phytase from
Pseudomonas aeruginosa p6. European Journal of Experimental Biology. 2; 95104.

Selvamohan, T., V. Ramadas and M. Rejibeula. (2012). Optimization of Phytase Production by Pseudomonas Sp. Isolated from Poultry Faces. International Journal of Modern Engineering Research, 2 (3): 1326-1330.

Simell M., Turunen M., Piironen J. and Vaara T., (199). Feed and Food Applications of Phytase. Lecture at $3^{\text {rd }}$ Meeting on Industrial Applications of Enzymes, Barcelona, Spain.

Singh, B. and Satyanarayana T. (2008). Phytase Production by a Thermophilic Mould Sporotrichim thermophile in Solid State Fermentation and its Potential Applications. Bioresource Technology 99:2824-2830.

Singh, B. and Satyanarayana, T. (2011). Phytases from Thermophilic Molds: Their Production, Characteristics and Multifarious Applications. Processing Biochemistry, Vol.46 (7), pp.1391-1398.

Vohra, A., and Satyanarayana, T. (2003). Phytases: Microbial Sources, Production, Purification, and Potential Biotechnological Applications. Critical Reviews in Biotechnology 23, 29.

Volfova, O., Dvorakova, J., Hanzlikova, A. and Jandera, A. (1994). Phytase from Aspergillus niger. Folia Microbiology. Vol.9, pp.481-484.

Yanke, L.J., Bae, H.D., Selinger, L.B and Cheng, K.J. (1998). Phytase Activity of Anaerobic Ruminal Bacteria. Microbiology, 144: 1565-1573.

\section{How to cite this article:}

Faith O. Ogbonna, Mohammed A. Milala, Mohammad Abubakar and Bulama Burah. 2017. Isolation and Optimization of Phytase from Pseudomonas aeruginosa and Aspergillus niger Isolated from Poultry Faeces. Int.J.Curr.Microbiol.App.Sci. 6(11): 3666-3673. doi: https://doi.org/10.20546/ijcmas.2017.611.429 